\title{
The Relationship of Principal Leadership and Organizational Climate on Motivation and Performance of Teacher in Primary School
}

\author{
Rita Ferdiana *, Ahmad Suriansyah, Suhaimi \\ Master Program of Education Management, Universitas Lambung Mangkurat, Banjarmasin 70123 \\ Indonesia
}

Article history:

Submission January 2020

Revised June 2020

Accepted June 2020

*Corresponding author:

E-mail: rita81168@gmail.com

\begin{abstract}
School is an institution where the educational process follows a complex and dynamic system. This study aimed to describe and analyze the effectiveness of the headmaster's leadership and organizational climate on achievement motivation and performance of teachers in the school setting. This research was correlational research using path analysis with 139 teachers as a sample and the data obtained was analyzed through the use of multiple regression methods. The results showed the effectiveness of the headmaster's leadership; organizational climate and teacher achievement motivation were included in the moderate category; while the teacher's performance was in a good category.
\end{abstract}

Keywords: Leadership effectiveness, organizational climate, achievement motivation, teacher performance

\section{Introduction}

The Indonesia Law on the Management of Legal Products, as well as the National Education System Article 35 paragraph 1, explains the elements of quality education to include standard contents, competency of graduates, knowledgeable education personnel, infrastructure, funding and education assessment which needs to be periodically planned and improved. This, therefore, makes the management of schools important (Suriansyah, 2011). This is mostly founded on the management of human resources (HR) to produce quality graduates following the needs of the community (Aslamiah, 2015).

The system of education used in Indonesia gives broad autonomy to schools and community involvement within the framework of national education policies (Suriansyah et al., 2014). This is to ensure schools are free to manage and allocate resources such as funds and learning materials according to priorities and in response to local needs (Suhaimi \& Efendi, 2018). Moreover, it is possible to improve the quality of education through the interconnection of work habits, work culture, and organizational culture (Poernawawijaya et al., 2018). According to Suhaimi \& Efendi (2018) the most important factor in achieving quality education in schools is through good leadership.

The success of a school is entirely dependent on the ability of the leader, the headmaster, to direct other employees towards the achievement of the school's goals (Normianti, 2019). The headmaster is responsible for the effective administration of all the departments as well as to present formal reports to the school management and informal report to the community (Suhaimi \& Khalik, 2018).

In addition to the headmaster's leadership, work motivation is an important part of school activities without which limited success would be recorded. According to Morgan, the concept 
is defined as the driving force or puller causing behavior towards a certain goal (Alamsyah et al., 2019). It, however, involves strategic organization through the utilization of several available resources, material, and human, to achieve the desired goals (Normianti, 2019).

In addition to the headmaster's leadership, work motivation is an important part of school activities without which limited success would be recorded. According to Morgan, the concept is defined as the driving force or puller causing behavior towards a certain goal (Alamsyah et al., 2019). It, however, involves strategic organization through the utilization of several available resources, material, and human, to achieve the desired goals (Normianti, 2019).

The results of a preliminary study conducted by the researchers found that the organizational climate in each of the SD Negeri Kota Kapuas as a whole was not very conducive, this was evidenced by the persistence of some teachers' behaviors that were not compliant with school regulations, some even had fatal consequences which led to dismissal because the teacher was absent for approximately 54 days a year.

Being aware of the professional and academic backgrounds of the teachers, this study aimed to determine the relationship between the effectiveness of school headmaster leadership and organizational climate on achievement motivation and performance of elementary school teachers in the Selat of Kapuas Regency.

\section{Material and Methods}

This research was correlational research using path analysis. According to Arikunto (2014) this method involves determining if there is a relationship or influence between two or more variables. Moreover, Gunawan (2016) stated that the path analysis model is used to analyze the pattern of relationships between variables and to determine the direct or indirect influence of a set of independent (exogenous) variables on the dependent variable (endogenous) (Normianti et al., 2019).

This research was carried out in the Strait district of Kapuas Regency from May to July
2019, was involving 17 schools and 139 teachers as samples (both civil and honorary civil servants).

\section{Data Collection}

The research instrument used was a closedquestions questionnaire and this involved the provision of several answers for the respondents to choose from. The variables used include Headmaster Leadership Effectiveness (X1), Organizational Climate (X2), Achievement Motivation (Y), and Teacher Performance (Z).

\section{Data Analysis}

The data obtained were analyzed by using SPSS version 22 . Analysis of the data used for each purpose was as follows: description of research data through descriptive statistical analysis (mean, maximum, minimum, range, variance, standard deviation), testing requirements of research analysis (normality test, linearity test, homogeneity test), test hypotheses with path analysis.

\section{Study Limitation}

This research focused only on the relationship of 4 (four) variables, namely the effectiveness of school principal leadership, the organizational climate on achievement motivation and teacher performance, and was only carried out in the Strait of Kapuas District so that the results cannot be generalized.

\section{Results and Discussion}

The aforementioned variables were described in the form of scores with the highest value being 5 and the lowest 1 . The tabulated data from each of the research variables are presented as follows: distribution of scores for headmaster effectiveness variables, distribution of organizational climate variable scores, distribution of achievement motivation variable scores, and distribution of performance variable scores. The average value obtained for the teacher performance was 3.88 which was categorized as high with the learning assessment sub-variable observed to have the highest average value of 4.22 which is was also in the high category. This means the elementary school teachers in the Selat district of Kapuas 
regency conducted learning assessments according to the lesson plan and necessary modifications are made in the next draft.

However, the learning planning sub-variable had the lowest average value of 3.52 which is also in the high category. This means there was no proper attention to the characteristics of students in the compilation of lesson plans and this reduce the effectiveness of strategies used in the teaching and learning process. Furthermore, the headmaster's effectiveness subvariable was found to have the smallest average value of 3.43 , but the value was still included in the high category. This means the average elementary school headmaster in the Selat district of Kapuas regency applied an effective leadership process by directly formulating goals, vision, mission as well as the annual plan of the school. The individual is also tasked with the responsibilities of developing methods of teaching students, extracurricular, and always strives to improve and excite teachers' work spirit.

\section{Data Normality Test Results}

This test was conducted to determine whether the dependent and independent variables have normal distributions or not. This study used of Kolmogorov-Smirnov one-sample method with Asymp Sig 2-tailed such that if the significance is less than 0.05 , the data is not normally distributed and vice versa. The results obtained are presented in the following table.

Table 1. Normality test results

One-Sample Kolmogorov-Smirnov Test

\begin{tabular}{|ll|r|r|r|r|}
\hline & $\begin{array}{r}\text { Effectiveness of } \\
\text { Headmaster Lead- } \\
\text { ership (X1) }\end{array}$ & $\begin{array}{c}\text { Climate Or- } \\
\text { ganization } \\
\text { (X2)) }\end{array}$ & $\begin{array}{c}\text { Achievement } \\
\text { Motivation (Y) }\end{array}$ & $\begin{array}{r}\text { Performance } \\
\text { (Z) }\end{array}$ \\
\hline N & Mean & 139 & 139 & 139 & 139 \\
Normal Parameters a,b & Std. Deviation & 129,3741 & 78,7266 & 71,9784 & 54,2518 \\
& Absolute & 5,55379 & 5,10443 & 4,09572 & 2,25251 \\
Most Extreme Differences & Positive &, 062 &, 113 &, 112 &, 117 \\
& Negative &, 062 &, 113 &, 112 &, 113 \\
Kolmogorov-Smirnov Z & &,- 056 &,- 094 &,- 079 &,- 117 \\
Asymp. Sig. (2-tailed) & &, 731 & 1,338 & 1,325 & 1,384 \\
\hline
\end{tabular}

a. Test distribution is Normal.

b. Calculated from data.

Source: SPSS Output 22, 2019.

Table 1 shows the significance value (Asymp Sig 2-Tailed) of the effectiveness of headmaster leadership effectiveness (X1) was 0.659 , organizational climate variables (X2) was 0.558 , achievement motivation variable (Y) was 0.597 , and teacher performance variable (Z) was 0.543 . Since all the significant values are more than 0.05 , the data in all the variables are normally distributed.

Furthermore, the regression analysis showed the indirect influence of headmaster leadership (X1) on teacher performance (Z) through achievement motivation (Y). The value of the path coefficient is shown in the following picture:

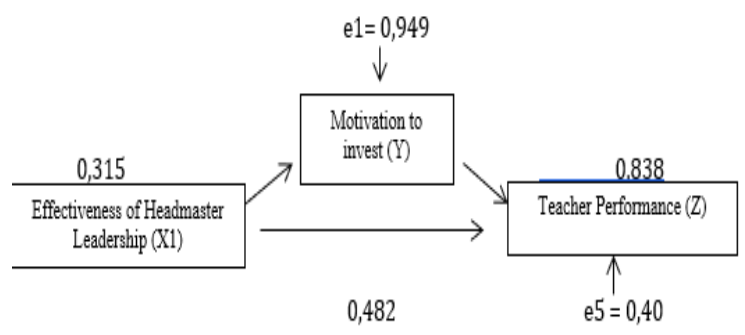

Figure 1. Trajectory Model of Relationships between X1 and Z through Y 


\section{Data Linearity Tesr Results}

The linearity test was conducted to determine whether there is a linear relationship between the research variables. SPSS was used in this study to test for linearity at a significance level of 0.05 . However, two variables are said to linearly related if the significance value is $<0.05$.

Table 2. Linearity test results of the relationship between the effectiveness of school headmaster leadership (X1), organizational climate (X2), achievement motivation $(\mathrm{Y})$ and teacher performance $(\mathrm{Z})$

\begin{tabular}{|c|c|c|c|}
\hline No. & Variable & Linearity & Information \\
\hline 1. & X1 dan Y & 0,000 & Linear \\
\hline 2. & X2 dan Y & 0,000 & Linear \\
\hline 3. & X1 dan Z & 0,000 & Linear \\
\hline 4. & X2 dan Z & 0,008 & Linear \\
\hline 5. & Y dan Z & 0,000 & Linear \\
\hline
\end{tabular}

Source: Data processed from research results, 2019

Table 2 showed the significance value obtained to be $0,000<0.05$ and this means the relationship between the headmaster leadership effectiveness (X1), organizational climate (X2), achievement motivation $(\mathrm{Y})$ and teacher performance $(\mathrm{Z})$ variables was linear.

Table 3. Homogeneity Test Results

\begin{tabular}{|c|c|c|c|}
\hline No. & Variable & P-value $/$ sig & Information \\
\hline 1. & X1 dan Y & 0,706 & Homogenous \\
\hline 2. & X2 dan Y & 0,424 & Homogenous \\
\hline 3. & X1 dan Z & 0,693 & Homogenous \\
\hline 4. & X2 dan Z & 0,122 & Homogenous \\
\hline 5. & Y dan Z & 0,914 & Homogenous \\
\hline
\end{tabular}

Source: SPSS Output 22, 2018

Table 3 shows the total $p$-value $>0.05$ and this means the data was obtained from a homo-

The analysis of the data provided is sumgeneous sample.

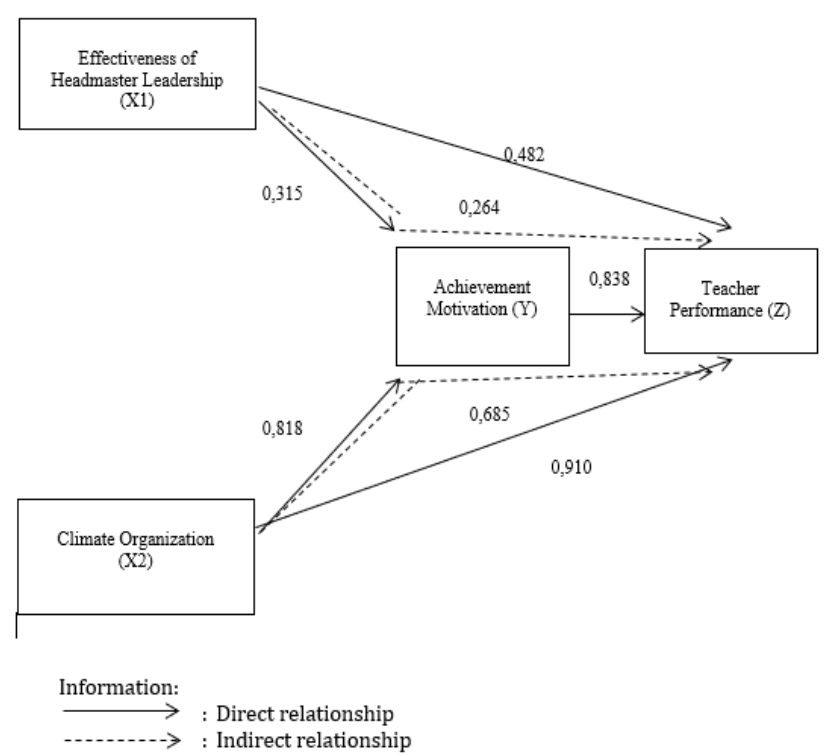

Figure 2. Analysis of the relationship between the effectiveness of headmaster leadership (X1), organizational climate $(\mathrm{X} 2)$, achievement motivation $(\mathrm{Y})$ and teacher performance $(\mathrm{Z})$ 


\section{Testing}

The hypothesis developed to determine the indirect relationship between organizational climate and performance through the achievement motivation include:

$\mathrm{HO}=$ there is no indirect relationship between organizational climate and teacher performance through achievement motivation.

$\mathrm{Ha}=$ there is an indirect relationship between organizational climate and teacher performance through achievement motivation.

The criterion for the acceptance or rejection of the hypothesis was that if the significance value $<0.05$ or the calculated $t$ value $>t$ table value for $n=139$, then $H 0$ was rejected and vice versa.

The indirect relationship between organizational climate variables (X2) and teacher performance (Z) through achievement motivation (Y) was obtained by multiplying the path coefficient of the direct relationship of variables X2 to $\mathrm{Y}(\mathrm{P} 2)$ with the path coefficient of the direct relationship of variable $\mathrm{Y}$ to $\mathrm{Z}$ (P5), which is mathematically $0.818 \times 0.838=0.685$. This means there is an indirect positive relationship between the organizational climate variable Teacher (X2) and the teacher performance variable (Z) through achievement motivation (Y) of 0.685 .

The mediation was tested by multiplying P2 x P5 $=0.685$, while the significance was calculated using the following equation:

Calculate the standard error of the indirect coefficient (Se23)

$$
\begin{aligned}
\text { Se25 } & =\sqrt{P_{5}^{2} \cdot S e_{2}^{2}+P_{2}^{2} \cdot S e_{5}^{2}+S e_{35}^{2} \cdot S e_{2}^{2}} \\
& =\sqrt{0,0011782331} \\
& =0,035
\end{aligned}
$$

From the Se23 results, the mediation relationship was calculated as follows:

$$
t=\frac{P_{25}}{S e_{25}}=\frac{0,685}{0,035}=19,571
$$

The value obtained is presented in the following table.

Table 4. Mediation Variable Relationship Test Results (X2 to Z through Y)

\begin{tabular}{|c|c|c|c|c|}
\hline Variable & Indirect Relations & $\mathbf{S}_{\text {indirect effect }}$ & $\mathbf{T}$ & Information \\
\hline $\mathrm{X} 2$ to Z through Y & 0,685 & 0,035 & 19,571 & Significant \\
\hline
\end{tabular}

Source: Calculation Results, 2019

Table 4 shows the overall organizational climate variables have a t-count greater than the t-table, with a significance level of 0.05 and this means $\mathrm{HO}$ is rejected, therefore, there is an indirect relationship between organizational climate and performance through achievement motivation.

Systematically, the factors correlating teacher professional performance are grouped into 5 components. The first includes the limited raw components input including the ability to understand as well as the skill to implement the curriculum. The second is the instrumental component input which involves the supervision of school/madrasah headmasters through observation, increasing teachers' professionalism and ability to develop curriculum. The third is the environmental input components including comfortable situations and conditions such that teachers are not distressed while focusing on students' progress. The fourth involves the process components which are planning and implementing learning, fostering relationships with students, conducting an assessment of results, implementing remedial, and conducting enrichment while the last include the output components.

\section{Conclusion and Recommendation}

Organizational climate is positively and sig 
nificantly related to achievement motivation of elementary school teachers in the Selat district of Kapuas regency. Moreover, the effectiveness of school headmaster leadership, organizational climate, and achievement motivation were in the medium category while the performance was in a good category. It is recommended that teachers have to develop the ability to plan learning activities more effectively through the use of strategies oriented towards the characteristics of each student and increment of decision making capability.

\section{Acknowledgment}

The author would like to thank all those who have helped so much that this research can be completed, especially to all respondents, the elementary school teachers in the Selat District of Kapuas Regency.

\section{References}

Alamsyah, Aslamiah, \& Muhyani, R. (2019). School based management implementation to improve school quality of multi sites study in SDN Alalak Selatan 2 and SDN Alalak Selatan 4 Banjarmasin City. International Journal of Scientific Development and Research (IJSDR), 4(1), 133-139

Arikunto, S. (2014). Prosedur Penelitian: Suatu Pendekatan Praktik. Jakarta: Rineka Cipta.

Aslamiah. (2015). Peningkatan mutu sekolah dasar melalui kepemimpinan transformasional kepala sekolah. Prosiding Seminar PS2DMP Unlam, 1(2), ISSN 2548-5598.

Gunawan, I. (2016). Metode penelitian kuantitatif: Teori dan Prak tik. Jakarta: Bumi Aksara.

Mulyasa, E. (2014). Menjadi guru profesional menciptakan pembelajaran kreatif dan menyenangkan. Bandung: Remaja Rosda Karya.
Normianti, H. (2019). Hubungan kepemimpinan transformasional kepala sekolah, motivasi kerja guru, komitmen organisasi guru dengan kinerja guru Sekolah Dasar Negeri Se-Kecamatan Labuan Amas Selatan. Banjarmasin: Universitas Lambung Mangkurat.

Rivai, V. (2018). Manajemen sumber daya manusia untuk perusahaan: Dari teori ke praktik. Jakarta: Raja Grafindo Persada.

Normianti, H., Aslamiah, A., \& Suhaimi. (2019). Relationship of transformational leaders of principal, teacher motivation, teacher organization commitments with performance of primary school teachers in Labuan Amas Selatan. European Journal of Education Studies, daring, 5(11), 123-141.

Suhaimi, \& Efendi, N. (2018). Hubungan peran kepala sekolah dan sikap terhadap profisi guru dengan prestasi kerja guru SMA Negeri di Kabupaten Hulu Sungai Selatan. Lentera: Jurnal Ilmiah Pendidikan, 13(1), 73-83. doi: https://doi.org/10.33654/jpl.v13i1.350

Suhaimi, \& Khalik, A. (2018). Kepemimpinan transformasional kepala sekolah pada SMP 4 Muhammadiyah. Jurnal Penelitian Tindakan dan Pendidikan., 4(1), 37-46.

Suriansyah, A. (2011). Pendidikan karakter dalam perspektif sistem pendidikan nasional. Jurnal Ilmu Pendidikan. 6(11), 117-130.

Poernamawijaya, L.W., Sulaiman, S., Suriansyah, A., \& Dalle, J. (2018). Contribution on supervision of supervisor, principals motivation, kindergarten teacher performance to improving the kindergarten quality in West Banjarmasin, Indonesia. European Journal of Alternative Education Studies, 3 (2),129-146. doi:10.5281/zenodo.2261031.

Suriansyah, A., Aslamiah, \& Sulaiman. (2014). Strategi pembelajaran. Jakarta: Raja Grafindo Persada.

Wirawan. (2014). Evaluasi kinerja sumber daya manusia teori aplikasi dan penelitian. Jakarta: Salemba Empat. 